\title{
COROLLARY DISCHARGE: ITS POSSIBLE IMPLICATIONS IN VISUAL AND OCULOMOTOR INTERACTIONS
}

\author{
Marc Jeannerod, Henry Kennedy and Michel Magnin
}

Laboratoire de Neuropsychologie Expérimentale, INSERM U 94, 16, avenue Doyen Lépine, 69500 Bron, France

\begin{abstract}
Data concerning the possible role of a corollary discharge mechanism in the regulation of visual-oculomotor interactions are reviewed. Several modes of action for such a mechanism on the processing of visual information are discussed. Mere suppression of visual input during saccades is considered mostly as a peripheral mechanism. It is proposed that corollary discharge could either produce an active cancellation of the effects of eye movements on vision, or contribute to the evaluation that a given visual change is provoked by a saccade. Cancellation could occur at subcortical levels of visual processing although evaluation could occur at the cortical level.
\end{abstract}

\section{INTRODUCTION}

THE QUESTION of how we feel our own actions is not a simple question. Besides inflow informations arising from peripheral receptors (visual, proprioceptive) and providing sensory cues as to the execution of a movement, another possibility has been postulated. At the beginning of the last century, the French philosopher Maine de Biran stated that actions must be revealed to the subject otherwise than by their effects, and that he must know them as such. Maine de Biran intuited that, without being caused by the will, muscular sensation (one of the effects of a movement) would only give us a purely passive feeling, as do heart beats or convulsive movements "that we feel without producing them purposively". Later, Helmholtz contributed to this notion by making the distinction, within what he called the muscular feeling, between two different sensations: the intensity of the effort of will, and the tension of the muscles.

The concept that efforts of will, which lead to the execution of a movement, have central neural (and recordable) correlates has been particularly emphasized by H. L. Teuber. By using the term corollary discharge (first coined by Sperry), Teuber assumed that "each voluntary movement or change of posture, involves not only the downward discharge to the peripheral effectors, but a simultaneous central discharge from motor to sensory systems preparing the latter to those changes that will occur as a result of the intended movement" $[1$, p. 198]. Teuber was in fact quite in the same line of thinking as Maine de Biran when he claimed that "presence or absence of corollary discharge . . . would determine whether a movement is voluntary or involuntary", and that "corollary discharge would serve as a physiological criterion for self-produced movements in contradistinction to reflexes" ([1] pp. 198-199; see also [2-4]). In his further descriptions, the terms voluntary and involuntary were often taken as equivalent for active and passive, respectively. This nuance may have more than a speculative interest.

In the literature, the merging of the concept of corollary discharge has been closely related to the problem of visual 'stability' during movements of the eyes. Helmholtz inter- 
preted this stability as due to the match between the impulse of will directed to the proper eye muscle, and its effect, i.e. the concomitant variation of the retinal image. Should there be a change in the retinal image without impulse of will (as in passively generated eye movements), or an impulse of will without a retinal change (as in paralysis of extra-ocular eye muscles), that an illusory displacement of the visual surroundings would become perceivable. SPERRY [5] more explicitly considered the possibility that "any excitation pattern that normally results in a movement that will cause a displacement of the visual image on the retina may have a corollary discharge into the visual centers to compensate for the retinal displacement". This mechanism was thought by Sperry as "an anticipatory adjustment in the visual centers specific for each movement with regard to its direction and speed". Finally, VON HOLST and MitTELSTAEDT [6] postulated that any command descending from a center to an effector produces a "closely correlated alteration in activity" (the "efference copy'), which spreads to other structures. "The efferent stream . . flowing out to the periphery evokes the corresponding reafference... from the effector, and this reafference interacts with the efference copy. The efference and its copy can be arbitrarily marked with a plus $(+)$ whilst the reafference is marked with a minus (-). The efference copy and the reafference exactly cancel one another out ...."Von Holst and Mittelstaedt specifically assumed that this mechanism could be at work in 'cancelling out' undesirable perceptual effects of eye movements.

Hence, the corollary discharge concept implies that outflow information (i.e. arising from efferent systems) can be used at the central level to regulate concomitant sensory messages. Though this notion is now widely admitted, this was not always the case. Particularly at the beginning of this century, Helmholtz's ideas were strongly refuted by the tenants of a purely reflex nature of behaviour. According to authors like JAMES [7] all incoming messages had to proceed through a sensory channel (i.e. from periphery to center), and the information flow within the brain had to be directed in the sensory-to-motor rather than in the motor-to-sensory direction. This 'reflex' theory is still an implicit framework in many experiments tending to minimize the role of a 'corollary discharge' type of mechanism.

Formal testing of the corollary discharge hypothesis has been attempted during the last decades in neurophysiological experiments. In the present paper, we discuss the possible relevance of these experimental data to the existence of a corollary discharge* in the visual centers, in relation to eyc movements. This choice does not imply that the visual and oculomotor interaction would have the unique privilege of such a regulation.

\section{NEUROPHYSIOLOGICAL CORRELATES OF COROLLARY DISCHARGE IN VISUAL CENTERS}

Although by definition CD implies central-to-central projections, the retina might also be a possible site for its action. This is an important point, since, due to the anatomical primacy of the retina, any modification in the processing of visual information at this level will be propagated through the other visual relays. In 1966, HoLden [8] had proposed that centrifugal fibers to the retina might play a role in certain visual changes associated to eye movements. However, the presence of centrifugal fibers, well documented in lower species, remains controversial in mammals, and particularly in man (see for instance [9]).

\footnotetext{
*We shall use throughout the terminology "corollary discharge" (CD) to designate both the general concept of motor-to-sensory interactions, and its possible physiological correlates.
} 
The only electrophysiological studies dealing directly with this problem have been carried out by NODA $[10,11]$ in the cat. This author showed that ganglion cells may respond to displacements of the retinal image in a similar way whether the displacement results from an active eye movement, or from an externally generated movement of the stimulus. This result seems to rule out the influence of a centrifugal signal concomitant to oculomotor activity.

\section{Geniculo-cortical pathway}

Lateral geniculate body, dorsal nucleus $(L G d)$. Many of the physiological studies dealing with the concept of CD have been carried out at the LGd level, for two main reasons. Anatomically LGd is the first synaptic relay in the visual pathway to striate cortex, where an interaction between visual input and an extra-retinal signal could possibly occur. Also the occurrence at this level of gross EEG potentials related to the rapid eye movements of paradoxical sleep, first disclosed in 1961 by MiKiTEN et al. [12] (see also [13, 14]) had drawn the attention to oculomotor influences on LGd. Great emphasis has been put on research into these potentials during sleep (PGO waves), but also in relation to saccadic eye movements in alert animals [15-17].

Single cell recordings at the $\mathrm{LGd}$ level in relation to saccades were started by JEANNEROD and PutKonen [18, 19] in encéphale isolé cats. These authors showed modifications of spontaneous unit activity tightly related to saccades in the dark. Similar results were obtained by CorazzA and LOMrroso [20] also in encéphale isolé cats, and by MONTERo and RoBLÈs [21] in the rat. The characteristics of saccadic modulation of LGd neurons in all three studies were very similar despite differences in data processing and elicitation of eye movements (spontaneous or of vestibular origin). In the dark, the effect of eye movements could be either excitatory or inhibitory, starting $30-40 \mathrm{msec}$ after the onset of the saccade, and lasting up to $160-200 \mathrm{msec}$. Saccadic modulation of geniculate neurons was later confirmed by MAGNIN et al. [22] in alert cats. They were able to show that $50 \%$ of LGd cells were modulated in relation to the fast phase of horizontal vestibular nystagmus, in the dark. The effect started $40-130 \mathrm{msec}$ after the onset of the saccade, and could last up to $250 \mathrm{msec}$. Unit activity could be increased or decreased for both directions of saccades, or increased for one direction and decreased for the other.

This question was rendered controversial by the failure of NoDA [23] to reproduce these results. In alert cats, this author was unable to show any significant modification of geniculate cells activity during spontaneous eye movements in the dark, although important changes appeared when the eye movements occurred in front of an illuminated grating. The same was true for a saccadic depression of LGd cells excitability in response to stimulation of the optic chiasm, which was apparent in the light condition, but not in the dark $[24,25]$.

At present, it remains difficult to reconcile the results of MAGNIN et al. [22] with those of Noda. Differences in experimental procedures could be responsible for the discrepancy. For instance, in Noda's studies, saccades were 'spontaneous', and results based on the inspection of unit recordings, whereas in Magnin's study, eye movements were elicited by rotational vestibular stimuli, and results based on histograms of unit discharge, which may reveal more subtle effects.

Similar discrepancies also exist between results obtained in the monkey LGd. BÜTTNER and FUCHS [26], in 1973, had shown that $95 \%$ out of 200 LGd units, in the alert monkey did not alter their activity during spontaneous saccades in the dark. The remaining $5 \%$ 
could increase or decrease their firing rate in relation to saccades quite in the same way as had been described by MAGNIN et al. [22] in the cat. More recently, however, BARTLETT et al. [27] were able to show consistent and important alterations in LGd responses evoked by stimulation of the optic tract during eye movements. LGd transmission was depressed during the saccade itself and was then facilitated about $100 \mathrm{msec}$ later. Even though this effect was more pronounced for saccades made in diffuse light or in front of a patterned environment, it was still present in dark. Finally, the magnocellular part of LGd was found to be more concerned than the parvocellular part. Differences in experimental procedure can hardly explain the differences in the intensity of the saccadic effects reported by BüTTNER and FuCHS [26] and by BARTLETT et al. [27]. An additional difficulty is that the few 'saccadic' cells recorded by Büttner and Fuchs were not located preferentially in the magnocellular part of LGd.

Understanding the functional connections of LGd might shed some light on the controversies raised by electrophysiological experiments. In fact, in the cat as well as in the monkey, there is a close similarity between effects observed at the LGd level, during eye movements, and during electrical stimulation of the brainstem reticular formation. By using WALL's technique [28], BILZI [29] and KAWAMURA and MARCHIAfava [30] were able to describe a depolarisation of optic tract endings, time-related to different types of eye movements (e.g. eye movements during sleep and in the midpontine preparation). This was considered as relatively dircet cvidence for presynaptic inhibition of primary optic afferents at the LGd entrance during eye movements. The same effect was obtained by stimulation of the mesencephalic reticular formation [3I-33]. More recently, however, SINGER and DRÄGER [34] were not able to replicate this finding. Instead, they noticed that reticular stimulation could produce a facilitation of geniculate transmission through a disinhibition of relay cells. This was confirmed by SINGER $[35,36]$ who in addition reported a transient post-synaptic inhibition preceding the disinhibition, which he attributed to an antidromic effect of the electrical stimulus, via bifurcated $Y$ fibers terminating in the brainstem. Finally, Singer and BEDwORTH [37] replicating the COHEN et al. [38] demonstration showed that both reticular stimulation and spontaneous saccades produced the same facilitation of LGd activity. They postulated that saccade contingent corollary activity serves to broaden the bandpass of geniculocortical channels and clear the LGd from postsynaptic inhibition which is generated by moving contrast during the saccade'.

A similar conclusion was reached by Tsumoro and SUzUKi [39]. In encéphale isolé cats, these authors found that electrical stimulation of the cortical frontal eye field produced an increase in spontaneous discharge in about one third of the recorded LGd neurons. Cells of the $\mathrm{X}$ type were predominantly affected by the stimulation. Hence, Tsumoto and SuzUKI suggest that the influence of saccades on LGd may be twofold. First, during the early part of the saccade $X$ cells receive a strong inhibition from the $Y$ system, produced by the rapid shift of the visual image on the retina [23, 37]. Second, during the late part of the saccade, $X$ cells are facilitated by an extra-retinal influence which cancels $X$ cells inhibition and thus improves transmission of foveal vision through LGd. This reasoning takes account of the effects on LGd of reticular as well frontal eye field stimulation. It seems supported by the results from FuKUDA and STONE [40] and FoOTE et al. [41] who show that $X$ and $Y$ LGd cells are differentially affected by reticular stimulation. Although the majority of $X$ cells are facilitated, $Y$ cells receive simultaneously a short latency inhibition.

Anatomical pathways have been described in the cat, which might represent a substrate 
for the extra-retinal influences of saccades at the LGd level. However, it still remains difficult to know which precise structures are directly and specifically involved in the phenomena occurring at the level of the LGd during saccadic eye movements. SCHEIBEL and SCHEIBEL [42] and BowsHER [43] have described afferent connections to the LGd from the magnocellular pontine reticular formation and from the mesencephalic tegmentum. Using Nauta's technique, Szentagothai [44] found evidence of direct projections from the anterior sigmoid gyrus (frontal eye fields), mesencephalic and upper pontine reticular formation to the perigeniculate nucleus. This author suggests that LGd cells could be influenced indirectly by the frontal cortex and the reticular formation via the perigeniculate nucleus. More recently, using horseradish peroxidase injections in the LGd, GILBERT and KELLY [45] and LEGER et al. [46] have found labelled cells in the raphé nuclei, the periaqueductal grey, the mesencephalic reticular formation, and in and around the locus coereleus.

Visual cortex. Experiments in search of visual and oculomotor interactions at the level of the visual cortex were greatly influenced by the negative findings of WURTZ in 1969 [47]. This author had been unable, in alert monkeys, to show a saccadic modulation of striate cortex (area 17) neurons, in the dark. The response of these neurons to visual stimuli however, was modified during eye movements. Simple cells, and cells with circular receptive fields became less selective in responding to visual stimuli, or in about $50 \%$ of cases, could even become totally unresponsive. Response of cells with complex or hypercomplex receptive fields was also suppressed during eye movements. Suppression of visual response of a large number of cortical cells during saccades can reflect an active process fitting the definition of a CD. However, in a subsequent paper WURTZ [48], comparing neuronal response when a saccade was made across an effective stationary stimulus, and when the same stimulus was moved saccadically in front of the immobile eye, could not find significant differences. From this result, he concluded to the absence of a CD mechanism in the striate cortex.

An experiment parallel to that of Wurtz was carried out in alert cats by NoDA et al. [49]. Neurons from cortical areas 17 and 18 were differentiated on the basis of their response to moving retinal images. Over half of the cells recorded only responded to movement between $12-100^{\circ} / \mathrm{sec}$ and gave no response to visual stimulation at velocities within the saccadic range. However, a small proportion $(10 \%)$ did respond to high velocities, and were influenced by saccades in front of a patterned background.

Approximately one half of this latter group of neurons were also influenced by saccades made in the dark, with a latency of 100-200 msec from the onset of saccades. Noda et al. rejected the idea that this effect could be the expression of a $\mathrm{CD}$, arguing that such a long delay would not be compatible with visual suppression during saccades. This conclusion however is a result of attributing to CD the unique function of 'saccadic suppression' (see below). In fact, according to our original definition, thechanges occurring during saccades in the dark in this small group of neurons do reflect a $C D$.

NoDs et al. [49] made further speculation that, although the majority of the neurons they recorded would not function during saccades, the group of cells responding to high velocities could signal the occurrence of a saccade, and, due to their short latency, could account for a role in cortical 'suppression' during saccades. This 'type of CD', however, being a purely sensory-to-sensory mechanism represents a serious departure from $\mathrm{CD}$ as previously defined.

Modification of cell discharge related to saccades in the dark remains a fundamental experimental criterion for CD. This could be observed by DuFFY and BURCHFIEL [50] in 
encéphale-isolé monkeys. A large majority of the neurons recorded in area 17 were found to be inhibited during saccades in a given direction. Histograms were necessary to demonstrate this effect however, which may explain the failure of the previous workers to demonstrate saccadic effects under the same conditions.*

An alternative experimental paradigm was used by ADEY and NODA [52] in an effort to examine the influence of eye movements on the excitability of the geniculo-striate pathway. In alert cats, the visual cortex response to electrical shocks applied to the optic chiasm was found to be altered during eye movements. Although the presynaptic component of the response was depressed only during saccades made in the light (a depression which was also observed in the same condition at the LGd level), the post-synaptic component was facilitated for a period of about $200 \mathrm{msec}$, peaking $150 \mathrm{msec}$ after the onset of the saccade. This enhancement occurred in relation to saccades made in the light as well as in the dark. The finding of a late cortical post-saccadic facilitation in the dark (which had been previously suggested by the single-unit studies of NODA ef al. [49]) has led ADEY and NODA [52] to propose that the visual cortex, rather than LGd is the site of visual and oculomotor integration. The fact that the decreased transmission in LGd and visual cortex occurs only with saccades in the light supports the notion that visual suppression during saccades is a peripheral (retinal) rather than a central phenomenon. Consequently, the inappropriate restriction of CD as being purely a mechanism directed at saccadic suppression is abandoned. Instead, the corollary mechanism is now interpreted as playing a role during the perceptual stage of visual processing, which would be in agreement with its peak activity some 150 $200 \mathrm{msec}$ after the initiation of the saccade.

Results from other studies are at variance with ADEY and NODA's [52]. WIESENFELD and HORN [53] in the cat, were able to find a light dependent reduction of LGd transmission, but found no evidence for a post-saccadic cortical facilitation. However, these authors pooled the post-saccadic potentials over a period of $500 \mathrm{msec}$. If indeed this is the cause of the discrepancy between the two sets of results it would seem to indicate that the facilitation is specifically related in a temporal fashion to the saccade. On the other hand, BARTLETT et al. [27] in the monkey, in addition to the above mentioned effects on LGd, have found that during saccades in the dark, cortical excitability shows an initial depression $(4.17 \%)$ followed by a subsequent facilitation (up to $21 \%$ ).

The differences between the results of ADEY and NODA [52] in the cat (who found only evidence of cortical post-saccadic facilitation in the dark), and of BARTLErT et al. [27] in the monkey (who found a dark-related post-saccadic depression in LGd and a dark-related depression followed by facilitation in the visual cortex), might be related to anatomical differences between the two species. Two main characteristics of the visual pathways seem to be relevant to this problem. (1) The identification of three neuron types in the visual system, $\mathrm{X}, \mathrm{Y}$ and $\mathrm{W}$, is now considered as an important issue [54, 55]. $\mathrm{X}$ type neurons might be devoted to the analysis of stationary visual features (e.g. form), while $Y$ and $W$ typcs would analyze movement $[56,57]$. Although most of this work has been carried out in the cat, a similar dichotomy is thought to exist in the monkey $[58,59]$. In contrast to the cat, it seems that in the monkey, the $\mathrm{X}$ and $\mathrm{Y}$ systems are morphologically segregated at the LGd level, the magnocellular layers constituting the $Y$ system, and the parvocellular layers, the $\mathrm{X}$ system [59]. It is precisely in the magnocellular compartment that BARTLETT

* However, a short report by VALlEala [ 51$]$ in alert monkeys had shown the occurrence of clearcut modifications of visual cortex neuron activity during saccades in the dark. 
et al. [27] have found saccadic effects in the dark. Absence of such effects in the cat could reflect that in this species there is no separation of $\mathrm{X}$ and $\mathrm{Y}$ cells in the laminated portion of the LGd. (2) Thalamo-cortical connections are different in cats and monkeys. While in the monkey, LGd projects only to area 17 [60], in the cat it projects to areas 17,18 and $19[60,61]$. Furthermore, in the monkey, cortical termination of $X$ and $Y$ systems remains distinct within area 17, since the parvocellular LGd compartment projects to cortical layers IVa and IVc and the magnocellular portion to layer IVb [62]. In the cat the X and $\mathrm{Y}$ systems constitute two parallel channels to the cortex, the $\mathrm{X}$ system terminating exclusively in area 17, and the $\mathrm{Y}$ system, in areas 17 and 18 [63]. Another difference is that in the cat the extrageniculate visual pathway is excluded from area $17[61,64]$, whereas in the monkcy area 17 receives afferences from tectorecipient areas of the pulvinar [65]. Hence, area 17 in the cat, reflecting exclusively geniculate input with a preponderance of the $\mathrm{X}$ system, would be more homogeneous than area 17 in the monkey.

Examination of saccade-locked events in different areas of the visual cortex could thus lead to a better comprehension of the functional significance of the interactions of $C D$ with the $\mathrm{X}$ and $\mathrm{Y}$ systems. Comparison of responses to velocity signals in areas 17 and 18 in the cat has led ORBAN and CALLens $[66,67]$ to propose that only cells in area 18 would give a response at stimulus velocities within the saccadic range. Accordingly, unit recording from a part of area 18 corresponding to the peripheral retina'had indicated a far greater proportion $(25 \%)$ of saccade-locked responses in darkness than NonA et al. [49] had previously shown in area 17 [68]. A similar proportion of neurons responding to saccades in the dark has been shown by KENNEDY and MAGNIN [69] in the Clare Bishop area of the cat, a zone also predominantly responsive to high velocity motion signals.

The anterior middle suprasylvian gyrus (area 7) in the cat, a visual association area, is known to receive thalamic visual input $[70,71]$. Unit recording at this level has shown a complex relationship of spontaneous activity with saccades, including neurons whose activity is modified before, during and subsequent to eye movements in the dark [72]. In monkey's area 7, a class of neurons has been shown to respond also before, during and subsequent to visually triggered saccades, but not spontaneous eye movements [73]. These authors discount the hypothesis that the activity of these neurons reflects a cortical manifestation of $C D$ on the grounds that these neurons are not strictly sensory and the response is dependent on the motivational state of the animal.

The fact that saccade-locked events are more important in extrastriate cortex than in area 17 is explicable anatomically if not functionally. The tectopulvinar pathway which terminates in the extrastriate cortex in the cat $[61,64,71]$ could convey at this level saccadic changes occurring in the superior colliculus (see below). In the monkey, where the tectopulvinar pathway terminates in striate and extrastriate cortex, the saccadic responses observed in the superior colliculus could conceivably be relayed to the striate cortex level. We have already seen that the presence in area 17 of such responses is a controversial issue. In addition, Wurtz and MohLER [74] using the 'enhancement' paradigm (see below) were able to show in area 17 only a slight effect following saccades, which they considered as non-specific and related to a general arousal. This absence of specific enhancement effect could be due to the fact that tecto-recipient pulvinar afferents terminate in cortical layers I and VI which are notoriously difficult to record. It is also possible that the enhancement phenomena observed in the superior colliculus could be relayed by inferor pulvinar to extrastriate visual cortex. This does not seem to be the case, since BAIzER and ROBINSON [75] failed to demonstrate saccade-locked events in monkey's prestriate cortex. 
The frontal eye field (area 8) also has neurons which modify its spontaneous activity during and subsequent to eye movements, both in the cat [76] and in the monkey [77]. Frontal lobes had been originally proposed by TEuBER [78] as being a likely candidate for the initiation of $\mathrm{CD}$. Such a standpoint has been progressively abandoned, however, because of the lack of evidence of an anatomical path by which frontal eye field could influence vision. SCHLAG et al. [79] had been able to show that stimulation of frontal eye field could induce recruiting responses in the visual cortex. This effect might be mediated via the intra laminar nuclei [64].

\section{Ventral nucleus of the iateral geniculate body and pregeniculate nucleus}

It seems well established that the ventral nucleus of the lateral geniculate body (LGv) and its simian homologue the pregeniculate nucleus (PGN) belong to the visual system. First, they have direct retinal afferents and are connected with many visual structures (see Ref. [80]). Second, the visual properties of their neurons have been precisely objectivated in neurophysiological experiments by Montero et al. [81], Mathers and MASCETti [82], SPEAR et al. [83] and HUGHES and ATFR [84]. Modulation of spontancous neuron activity in relation to saccades of these structures has been demonstrated in monkeys [26] and in cats $[22,85]$. Hence, it would be of particular interest, as stressed by SPEAR et al. [83] to know whether these two basic characteristics (visual and saccadic) could be reflected by the same cell. In the Büttner and Fuchs study, 50\% of the recorded cells showed both responses to flashes of light and modulation by saccades in the dark. The authors, considering the long latency (about $80 \mathrm{msec}$ ) of the saccadic effect, concluded that this convergence on PGN neurons of visual and oculomotor inputs could not account for a central suppression phenomenon. Nevertheless, their results represent a good example of what could be a CD.

In the cat, the work of the above mentioned authors [85], recently confirmed by MAGNIN and PutKonen [86], showed that $50 \%$ of the recorded LGv cells modified their activity in relation to saccades, but do not present any response to visual stimuli. This is confirmed by the fact that the saccadic response is the same whether the saccade is made in the dark or in front of an illuminated pattern. The characteristics of the saccadic responses are different from those recorded in the monkey PGN: particularly, in the cat, a significant number of neurons begin to respond about $30 \mathrm{msec}$ prior to the onset of the saccade. Finally, a strong vestibular input has been shown in the cat LGv $[22,85,86]$, affecting the saccadic cells, but not the visual ones. Such a vestibular input could not be found in PGN neurons [87]. Thus, it seems that, unlike the monkey PGN, the cat LGv cannot be assigned a function in oculomotor and visual interactions, until the link between its two distinct neuronal populations has been established.

\section{Retino-tectal pathways}

Relationship of the tectum with eye movements is complex. Particularly, the superior colliculus (SC) a sensory structure, also acts as a 'premotor' area for eye movements, a property which has been largely established by stimulation expcriments in cats [88] and in monkeys [89]. This dual role of SC implies that, before eye-movement-related activities can be ascribed to a possible $C D$, they must be clearly distinguished from possible 'command' discharges. In fact although CD should be manifested only by the sensory part of the structure, eye-movement-related activities from the motor part will also be described as possible sources of $C D$.

In the cat, eye-movement-related activities have been recorded from SC neurons in 
encéphale-isolé preparations, by STRASCHILL and HofFManN [90]. Visual direction selective neurons were found to be influenced by saccades in $76 \%$ of cases. In $53 \%$, the saccade was effective in changing neurone activity only when the eye moved in front of a lighted pattern (type I). In that case, the most effective direction of the saccade in firing the unit was opposite to the preferred visual direction. In $23 \%$ of cases, neurone activity was modified in relation to eye-movements in the dark, with increased $(10 \%$, type III), or decreased ( $13 \%$, type IV) discharge rate. In types III and IV, the change in discharge rate could sometimes precede the onset of the eye-movement, or coincide with it. Although they do not indicate the precise location of the recorded neurons, Straschill and Hoffman think that they are sensory movement-detectors, and that saccade-locked activity must be due to the convergence on these neurons of an input of extra-retinal origin. Arduini et al. [91], also in the encéphale-isolé cat found a modulation of firing related to saccades in the dark, in $82 \%$ of their sample of collicular neurons. The change in firing rate occurred before the saccade (up to a $100 \mathrm{msec}$ ) whether it was spontaneous or induced by vestibular stimulation (see also [92]). The difference between these results and those of STRASCHILL and HofFMANN [90], who reported only $23 \%$ of neurons influenced by saccades in the dark can be explained by the difference in neuronal population sampled. Neurons recorded by Arduini et al. were mostly located in the deep layers, and could thus be classified as 'motor' neurons.

Similar changes in pretectal structures, recently described by BoN et al. [93] in the cat, are also worth mentioning. These authors show that neurons from the nucleus of the optic tract and from nucleus pretectalis posterior (which both receive direct visual input) are activated within a short delay after saccades made in the dark. They suggest that pretectal neurons might be involved in post-saccadic 'facilitation'.

Saccade-related changes in excitability of collicular afferents have been studied by HAYASHI et al. [94]. These authors found, in chronically implanted cats, that the field potentials evoked in superficial layers of the superior colliculus by electrical stimulation of the optic tract were modified when spontaneous saccades occurred in the dark. The post-synaptic $\mathrm{C}_{2}$ and $\mathrm{C}_{3}$ components of the evoked responses were enhanced within about $200 \mathrm{msec}$ following saccade onset. Since the $\mathrm{C}_{\mathbf{3}}$ component is believed to reflect the activity of direct slow (W) retino-tectal fibers, its enhancement during saccades must be due to a change in excitability at the $\mathrm{SC}$ level. The $\mathrm{C}_{2}$ component reflects the activity of fast indirect $Y$ fibers reaching the colliculus after having relayed in LGd and visual cortex. Its enhancement might thus correspond to an increased excitability at geniculate or cortical levels. However, NAGATA and HAYASHI [95], by stimulating the cortico-tectal fibers during eye movements, have been able to show that only the post-synaptic component of the response was enhanced. This confirms the idea that an extra-visual input reaches the sensory part of the superior colliculus at the time of saccades in the cat.

In the monkey, the difficulty to interpret the nature of eye-movement related discharges has led to a number of interesting experiments. In the superficial (visual) layers of the SC, saccades act upon the visual responses of the cells in a complex fashion. According to WURTZ and MOHLER [96], the visual response of a given neuron is enhanced if the visual stimulus stimulating its receptive field is used as a target for the saccade. This enhancement effect is not observed if the saccade was directed at a stimulus located well outside the receptive field. In other studies from the same laboratory, the visual responses of cells from the superficial layers were compared when the movement of the retinal image resulted from a brisk displacement of the visual stimulus, or was produced by a saccade. Most $(61 \%)$ of the cells which responded to high stimulus velocities were found to distinguish 
between rcal movement and self-induced movement, in the sense that they did not respond to a retinal movement produced by a saccade. These cells also showed a brief suppression of their spontaneous activity after a saccade. This effect persisted in the dark [97, 98]. Robinson and Wurtz conclude that the failure to respond to visual movement during saccades relies upon the same extra-retinal mechanism which produces the post-saccadic suppression or inhibition.

Within the decpest collicular layers of the monkey, typical 'motor' discharges were observed. These neurons are non-visual and increase their discharge rate prior to saccades in a given direction [99, 100]. In subsequent experiments both SCHILLER and STRYKER [101] and Goldberg and Wurtz [97] found similar 'motor' cells within the deep layers, but presenting a clearly defined visual receptive field. According to Schiller and Stryker, "the receptive fields of such units were located in that part of the visual field to which the fovea was directed by the saccade, which was associated with unit activity."

More recently, MOHLLR and WURT7 [102] have made a distinction between two classes among the eye-movement cells in the deep and intermediate layers: (1) Pure eye-movement cells (with or without visual receptive field) would correspond to the motor cells described by SCHILler and Stryker [101] and by GoldberG and Wurtz [97]. (2) Visually triggered movement cells have the same 'motor' characteristics as pure eye-movement cells (i.e. discharge prior to saccades in a given direction), but are also 'sensory' since they exhibit their saccadic properties only when the saccade is directed at a visual stimulus appropriately located. These cells are localized at the border between superficial and intermediate layers. Pure eye movement cells and visually triggered eye movement cells both reflect the animal's readiness to make an eyc movement.

WURT7 and MOHLER's model [96] attempts to fit these data: first, visual input (from the superficial layer cells) and eye-movement input (from the pure eye-movement cells in the deep layers) would both converge upon the visually triggered eye-movement cells in the intermediate layer. These 'visuo-motor' neurons would represent an important output from the SC for the control of visuo-motor behaviour. Second, purely sensory visual cells (from the superficial layer) would receive an additional motor input from the pure eye-movement cells. This motor-to-sensory pathway would fit the definition of a corollary discharge mechanism, hence explaining the post-saccadic effects (suppression and/or enhancement) observed at the sensory level. Although this model rejects the classical view of a visual-tomotor organization of $\mathrm{SC}$, its authors do not suggest that it excludes the role of $\mathrm{SC}$ in foveation.

\section{POSSIBLE FUNCTIONS OF COROLLARY DISCHARGE IN VISUAL AND OCULOMOTOR INTERACTIONS}

It seems hard to draw from the neurophysiological results a unique and clearcut function for a CD arising from eye movements and propagating to the visual system. However, if one admits that the visual system needs to be 'protected' from the effects of eye movements, and that $C D$ is the mechanism by which this function is achieved, then several possible modes of action can be discussed.

\section{Saccadic suppression}

Saccadic suppression, a transient rise in perceptual threshold during saccades in man, known in the psychophysical literature as early as ERDMANN and DODGE [103] could represent the way by which perception of visual smear and of other distortions of visual 
input during saccades, is avoided. This effect may start some $40 \mathrm{msec}$ prior to the onset of a saccade and last up to $100 \mathrm{msec}$, i.e. up to the beginning of the next fixation. Saccadic suppression affects perception of dim flashes [104-106] of image displacements [107] as well as the corresponding cortical evoked potentials [108-110]. It has also been shown to affect the perception of 'phosphenes' generated by central stimulation [111, 112]. An extensive review of the phenomenon of saccadic suppression can be found in MATIN [113].

Saccadic suppression has been early attributed to a central mechanism (central 'anaesthesia' of HoLT, [114]) and has been often considered as virtually synonymous for corollary discharge (e.g. [115]). Psychophysical experiments, starting with that of MACKAY in 1970, [116] had rather suggested that retinal factors might be responsible for saccadic suppression. The perceptual phenomenon is more pronounced when the eyes scan a structured background than a blank field [117]. It does not occur when the subject attempts to make saccades with a paralyzed eye [118]. The same suppression effect can be obtained when a visual pattern is suddenly displaced in front of an immobile eye [116, 119].

The notion of a saccadic suppression generated at the retinal level is in concordance with neurophysiological results. COHEN and FELDMAN [120] in the monkey, and MALCOLM et al. [121] and WIESENFELD and HORN [53] in the cat had shown that geniculate transfer was depressed during eye movements, but that this effect could be observed only when the eye was moved in front of a lighted background. Furthermore, a transient decrease in geniculate and cortical visual evoked potentials can be provoked in the cat by a rapid displacement of the visual field in front of the immobile eyes [52, 122].

Hence, the retinal signals generated by image displacements during eye movements could be a sufficient cause for 'masking' other concomitant visual signals. There are no direct neurophysiological explanations for such a phenomenon: however, the shift-effect reported at the retinal level by KRÜGER and FISHER [123] could represent a tentative basis.

Although the main contribution to saccadic suppression is certainly of a retinal origin this may not be the only explanation. As pointed out by BRIDGEMAN [124] two mechanisms (visual and extra-visual) could operate in a complementary fashion. Saccadic suppression would be primarily of visual (retinal) origin in the photopic condition, i.e. when the eyes are scanning a structured field, extra-visual inhibition would come into play in the scotopic condition, i.e. when the retinal factor is minimal. This theory has the advantage to reconcile conflicting data. Furhermore, it implies that saccadic suppression does have a physiological role rather than being only due to an inbuilt constraint of the transfer of information within the visual pathways during eye movements.

\section{Stabilization}

Other psychophysical findings have been considered as corroborative evidence of a role of $\mathrm{CD}$ in visual stabilization during eye movements. If the eye is prevented from movement, either by mechanical hindrance or muscular paralysis, displacement of the visual world is experienced in the direction of an attempted saccade [125-127]. The perceived displacement of the visual world can thus be attributed to an extra-retinal signal which parallels the oculomotor signal. In normal vision the extra-retinal signal interacts with the visual response derived from retinal shift and results in perception of a stabilized visual world. When however care is taken to ensure total immobilization of the eye, then no displacement is experienced during attempted saccades [128-130]. This difference in perceptual effects between the experiments with partial or total paralysis could be taken to support the notion that 
proprioceptive information from extra-ocular muscles plays a role in stabilization of vision during saccades $[119,131,132]$. There is no direct proof for this, however.

Stability of the visual world during saccadic cye movements can be considered as an example of a vaster problem of how an animal evaluates sensory inflow when its own movement entails a modification of that sensory inflow. Hence experiments designed to explore perceptual experience during saccades are pertinent not only to stabilization but to a more general theory of information processing by the animal. It is along these lines that we can consider the work of MacKay. From the view of information engineering he argues that the central nervous system would need to have corollary information concerning the location and movement of mobile sense organs [133]. In his paper, substantial arguments are presented to support the notion that the interaction between corollary and sensory information would not be a simple algebraic one resulting in a cancellation as proposed by the efference copy model of VON HOLST and MirTElstaedT ([6], see introduction). To prevent sensory information being ambiguous it would need to be evaluated in terms of the corollary information concerning the exploration of the environment by the sense organ. The idea of corollary information being used to evaluate sensory inflow rather than to cancel out artefacts introduced by movements of the animal is central to MacKay's reasoning. Not only is the evaluative CD model in strict opposition to the mechanism of cancellation, but it also does not require any anticipation with respect to the movement, which is inherent in a CD-cancellation theory. Hence the evaluation model suggests the possibility of a very different temporal relationship of the CD to sensory inflow. No longer is the CD scen to be required uniquely during the saccades but conceivably could be directed at later, perceptual stages of information processing. Except for the cells found by RoBINSON and WURTz [98] in monkey SC, the majority of neurophysiological findings show tardive saccadic influences of visual neurons, and therefore can be more easily included into an evaluative model of $C D$.

Keeping MacKay's definition of $\mathrm{CD}$ as an evaluation process in mind it is perhaps possible to throw some light on the apparent contradiction of the results obtained from experiments with partially and totally paralysed eyes. In partial paralysis it is the mismatching of the CD concerning the attempted saccade and the signal originating from the actual retinal shift which would give rise to the perceptual illusion. However in the totally paralysed state there is no movement of the visual image on the retina and hence no sensory input into those visual centers dealing with movement perception. It is precisely these centers which, in the evaluative CD model would be expected to be the target of CD.

At this point it becomes possible to delineate a conceptual frame for the role of CD in different structures. In the WURTz and MOHLER [96] model of SC function, the movement related cells of the intermediate layer provide the extra-retinal signal to the visual cells of the superficial layer. This CD is responsible for the selective enhancement of the superficial cells as well as their ability to differentiate movement of the visual world from that caused by eye movements. Eye movement response is precocious and it is thus possible for the CD to anticipate the retinal shift signal resulting from eye movements. This fulfills an essential criterion of an efference copy or cancellation CD model.

However, the authors proposed that the reflection of readiness to respond of the deeper lying SC cells is also fed into the visual cells as part of the extra-retinal signal. The readiness to respond of the motor cells is converted into the selective enhancement of the visual cells. The ability of monkey $\mathrm{SC}$ to detect real movement, and the enhancement of stimuli likely to initiate an eye movement are combined into a concept of $\mathrm{SC}$ involvement in selective 
attention. Presumably the agency of the $\mathrm{SC}$ in directing eye movements to salient features of the environment requires the elimination and not evaluation of self produced motion on the retina.

The proposition that a cancellation CD model might be operant in certain structures and an evaluation $C D$ model in others is not surprising if the origins of these two CD theories are considered. The term efference copy was originally used to describe the optomotor orientation of insects [6]. The SC is involved with orientation behaviour, which can bypass higher perceptual brain functions. MACKAY and MitTELSTAEDT [133] argued that the cancellation theory would not adequately maintain an internal representation of the environment, and proposed their evaluative model of $\mathrm{CD}$ function. Conceivably such an evaluative function of $C D$ would be more appropriate to cortical levels of visual information processing, whilst a cancellation model might be applicable to SC function.

\section{REFERENCES}

1. Teuber, H. I. Alterations of perception after brain injury. In Brain and Conscious Experience, J. C. ECCLES (Editor), pp. 182-216. Springer, New York, 1966.

2. Teuber, H. L. L'hypothèse des décharges corollaires. In La Fonction du Regard, A. Dubois Poulsen, G. C. LAIRY et A. Remond (Editors), pp. 187-198. 1971. INSERM, Paris.

3. Teuber, H. L. Perception et mouvement. Aspects neurophysiologiques et psychophysiologiques. In Neuropsychologie de la Perception Visuelle, H. HÉCAEN (Editor), pp. 187-221. Masson, Paris, 1972.

4. Teuber, H. L. De la perception à la mémoire: questions centrales en Neuropsychologie. Lyon Med. 236, 661-671, 1975 .

5. SpERry, R. W. Neural basis of the spontaneous optokinetic response produced by visual inversion. J. Comp. Physiol. Psychol. 43, 482-489, 1950.

6. Holst, E. von and Mittelstaedt, H. Das Reafferenzprinzip. Wechselwirkungen zurischen Zentralnervensystem und Peripherie. Naturwiss. 37, 464 476, 1950.

7. JAMEs, W. The Principles of Psychology. Macmillan, London, 1890.

8. Holden, D. L. Two possible visual functions for centrifugal fibres to the retina. Nature, Lond. 212, $837-838,1966$.

9. Reperant, J. and Galiego, A. Fibres centrifuges dans la rétine humaine. Arch. Anat. Microsc. Morphol. Exp. 65, 103-120, 1976.

10. NODA, H. and ADEY, W. R. Retinal ganglion cells of the cat transfer information on saccadic eye movements and quick target motion. Brain Res. 70, 340-345, 1974.

11. NoDA, H. Sustained and transient discharges of retinal ganglion cells during sponianeous eye movements of cat. Brain Res. 84, 515-529, 1975.

12. Mrkiten, T. M., Niebyl, P. H. and Hendley, L. D. EEG desychronisation during behavioural sleep associated with spike discharges for the thalamus of the cat. Fedn. Proc. 20, 327, 1961.

13. Brooks, D. C. and Bizzi, E. Brainstem electrical activity during deep sleep. Arch. Ital. Biol. 101, $648-666,1963$.

14. Michel, F., Jeanierod, M., Mouret, J., Rechtschaffen, A. and Jouvet, M. Sur les mécanismes de l'activité de pointes au niveau du système visuel au cours de la phase paradoxale du sommeil. $C$. $R$. Soc. Biol. 78, 103-106, 1964.

15. Feldman, M. and Cohen, B. Electrical activity in the lateral geniculate body of the alert monkey associated with eye movements. $J$. Neurophysiol. 31, 455-466, 1968.

16. Brooks, D. C. Waves associated with eye movements in the awake and sleeping cat. 24, 532-541, 1968.

17. Jeannfron, M. and SAKAI, K. Occipital and geniculate potentials related to eye movements in the unanesthetized cat. Brain Res. 19, 361-377, 1970.

18. Jeanierod, M. and PutkoneN, P. T. S. Oculomotor influcnces on lateral geniculate body neurons. Brain Res. 24, 125-129, 1970.

19. Jeannerod, M. and Putkonen, P. T. S. Lateral geniculate unit activity and eye movements: saccadelocked changes in dark and in light. Expl Brain Res. 13, 533-546, 1971.

20. Corrazza, R. and Lombroso, C. T. The neuronal dark discharge during eye movements in the cat. Brain Res. 34, 345-360, 1971.

21. Montero, V. M. and Robles, L. Saccadic modulation of cell discharges in the lateral geniculate nucleus. Vision Res. Suppl. 3, 253-268, 1971.

22. Magnin, M., Jeannerod, M. and Putkonen, P. T. S. Vestibular and saccadic influences on dorsal and ventral nuclei of the lateral geniculate body. Expl Brain Res. 21, 1-18, 1974. 
23. NODA. H. Discharge of relay cells in lateral geniculate nucleus of the cat during spontaneous eye movements in light and darkness. J. Physiol., Lond. 250, 579-595, 1975.

24. NODA, H. and ADEY, W. R. Excitability changes in cat lateral geniculate cels during saccadic eye movements. Science 183, 543-545, 1974.

25. NodA. H. Depression in the excitability of relay cells of lateral geniculate nucleus following saccadic eye-movements in the cat. J. Physiol., Lond. 249, 87-102, 1975.

26. BütTNER, U. and FUCHS, A. F. Influence of saccadic eye movements on unit activity in simian lateral geniculate and pregeniculate nuclei. $J$. Neurophysiol. 36, 127-141, 1973.

27. BARTLeT, J. R., Doty, R. W., LeE, B. B. and SAKakURA, H. Influence of saccadic eye-movements on geniculostriate excitability in normal monkeys. Expl Brain Res. 25, 487-509, 1976.

28. WALI, D. D. Excitability changes in afferent fibre terminations and their relation to slow potentials. J. Physiol., Lond. 142, 1-21, 1958.

29. BIzzI, E. Changes in the orthodromic and antidromic response of optic tract during the eye-movements of sleep. J. Neurophysiol. 29, 861-870, 1966.

30. Kawamera, $\mathrm{H}$. and Marchiarava, P. L. Modulation of transmission of optic nerve impulses in the alert cat: evidence of pre-synaptic inhibition of primary optic afferents during ocular movements. Brain Res. 2, 213 215. 1966

31. Angel, A. Magni, F. and Strata, P. Evidence for a presynaptic inhibition in the lateral geniculate body. Nature, Lond. 208, 495-497, 1965.

32. Kahn, N. Magni, F. and Pillat, R. V. Depolarization of optic fiber endings in the lateral geniculate body. Arch. Ital. Biol. 105, 573-582, 1967.

33. Pecci-SaAvedra, J., Wilson, P. D. and Doty, W. Presynaptic inhibition in primate lateral geniculate nucleus. Nature, Lond. 210, 740-732, 1966.

34. Singer, W. and DräGier, U. Postsynaptic potential in relay neurons of cat lateral geniculate nucleus after stimulation of the mesencephalic reticular formation. Brain Res. 41, 214-220, 1972.

35. Singer, W. The effect of mesencephalic reticular stimulation on intracellular potentials of cat lateral geniculate neurons. Brain Res. 61, 35-54, 1973.

36. SiNGER, W. Brainstem stimulation and the hypothesis of pre-synaptic inhibition in cat lateral geniculate nucleus. Brain Res. 61, 55-68, 1973.

37. Singer, W. and BedworTi, N. Correlation between the effects of brainstem stimulation and saccadic eye movements on transmission in the cat lateral geniculate nucleus. Brain Res. 72, 185-202, 1974.

38. Cohmen, B., Feldman, M. and Diamond, S. P. Effects of eye movements brainstem stimulation and alertness on transmission through lateral geniculate body of monkey. $J$. Neurophysiol. 32, 583-594, 1969.

39. Tsumoto, T. and Suzuki, D. A. Effects of frontal eye field stimulation upon activities of the lateral geniculate body of the cat. Expl Brain Res. 25, 291-306, 1976.

40. FLKUdA, Y. and Stonf, J. Evidence of differential inhibitory influences on $X$ - and Y-type relay cells in the cat's lateral geniculate nucleus. Brain Res. 113, 188-196. 1976.

41. Foote, W. E., Mordes, J. P., Colby, C. L. and Harrisson, T. A. Differential effect of midbrain stimulation on X-sustaincd and Y-transient neurons in the lateral geniculate nucleus of the cat. Brain Res. 127,153 158, 1977.

42. SCheibel, M. E. and Scheibel, A. B. Structural substrates for integrative patterns in the brainstem reticular core. In Reticular Formation of the Brain. H. JASPER (Editor), pp. 31-55. Little, Brown, Boston, 1958.

43. Bowsher, D. Reticular projections to lateral geniculatc in cat. Brain Res. 23, 247-249, 1970.

44. Szeniagothai, J. Lateral geniculate body structure and eye movement. Bibl. Ophthal. 82, 178-188, 1972.

45. Gilbert, C. D. and Kelly, J. P. The projections of cells in different layers of the cat's visual cortex. $J$. comp. Neurol. 163, 81-106, 1975.

46. Leger, L. Sakat, K., Salvert, D. Mouret, M. and Jouvet, M. Delineation of dorsal lateral geniculate afferents from the cal brainstem as visualized by the horscradish peroxydase technique. Brain Res. 93, 490-496, 1975.

47. WURTZ, R. H. Response of striate cortex neurons to stimuli during rapid eye movements in the monkey. J. Neurophysiol. 32, 875-986, 1969.

48. WURTY, R. H. Comparison of effects of eye movements and stimulus movements on striate cortex neurons of the monkey. J. Neurophysiol. 32, 987-994, 1969.

49. Noda, H., Freeman, R. B. and Creutzfeldt, O. D. Neuronal correlates of eye movements in the visual cortex of the cat. Science, 175, 661-664, 1972.

50. DefFy, F. H. and BuRCHFieL, J. L. Eye movement related inhibition of primate visual neurons. Brain Res. 89, 121-132, 1975.

51. Valleala, P. Nystagmus and the activity of visual cortex cells. Experientia 24, 358, 1968. 
52. ADEY, W. R. and NODA, H. Influence of eye movements on geniculo-striatc excitability in the cat. $J$. Physiol., Lond. 235, 805-821, 1973.

53. Wiesenfeld, $Z$. and HorN, $G$. The effects of eye movement and dark-adaptation on transmission through the visual pathways of unrestrained cats. Brain Res. 77, 211-219, 1974.

54. Enroth-Cugell, C. and Roson, J. G. The contrast sensitivity of retinal ganglion cells of the cat. $J$. Physiol., Lond. 187, 517-552 (1966).

55. Hoffman, K. P., Stone, J. and Murray Sherman, S. Relay of receptive field properties in dorsal lateral geniculate nucleus of the cat. $J$. Neurophysiol. 35, 518-531, 1972.

56. Cleland, B. G., Dubin, M. W., LFVick, W. R. Sustained and transient neurons in the cat's retina and lateral geniculate nucleus. J. Physiol., Lond. 217, 473-496, 1971.

57. IKEDA, H. and WRIGHT, M. Y. Receptive field organization of 'sustained' and 'transient' retinal ganglion cells which subserve different functional roles. J. Physiol., Lond. 227, 769-800, 1972.

58. Sherman, S. M., Wilson, J. R., KaAs, J. R. and Webb, W. V. X-and Y-cells in the dorsal lateral geniculate nucleus of the owl monkcy (Aotus trivirgatus). Science 192, 475-476, 1976.

59. DReHER, B., FUKUDA, Y. and RODIECK, R. W. Identification, classification and anatomical scgregation of cells with $\mathrm{X}$ - and $\mathrm{Y}$-like properties in the lateral geniculate nucleus of old world primates. J.Physiol., Lond. 258, 433-452, 1976.

60. WILSON, M. E. and CRAGG, B. G. Projections from the lateral geniculate nucleus in the cat and monkey. J. Anat. 101, 677-692, 1967.

61. MACIEwICZ, R. J. Thalamic afferents to areas 17,18 and 19 of cat cortex traced with horseradish peroxidase. Brain Res. 84, 308-312, 1975.

62. Hubel, D. H. and Wirsel, T. N. Laminar and columnar distribution of geniculo-cortical fibres in the macaque monkey. J. comp. Neurol. 146, 421-450, 1972.

63. STONE, J. and Dreher, B. Projection of X-and Y-cells of the cat's lateral geniculate nucleus to areas 17 and 18 of visual cortex. J. Neurophysiol. 36, 551-567, 1973.

64. KENNEDY, H. and BALEYLIER, C. Direct projections from thalamic intralaminar nuclei to visual cortex in the cat traced with horseradish peroxydase. Expl Brain Res. 28, 133-139, 1977.

65. Benevento, L. A. and RezAK, M. The cortical projections of the inferior pulvinar and adjacent lateral pulvinar in the rhesus monkey (Macaca mulatta: an autoradiographic study. Brain Res. 198, 1-24, 1976.

66. Orban, G. A. and Callens, M. Receptive field types of area 18 neurons in the cal. Expl Brain Res. 30, 107 124, 1977.

67. ORban, G. A. and Caluens, M. Influence of movement parameters on area 18 neurons in the cat. Expl Brain Res. 30, 125-140, 1977.

68. Orban, G. and Callens, M. Influence of saccadic eye movements on area 18 neurons in the cat. Arch. Internat. Physiot. Biochem. 82, 364-366, 1974.

69. KENNEDY, H. and MAGNIN, M. Saccadic influences on single neurone activity in the medial bank of the cat's suprasylvian sulcus (Clare Bishop area). Expl Brain Res. 27, 315-317, 1977.

70. Heath, C. H. and Jones, E. G. The anatomical organization of the suprasylvian gyrus of the cat. Ergebn. Anat. Entwickl. Gsch. 45, 3, 1971.

71. Graybiel, A. M. Some extrageniculate visual pathways in the cat. Invest. Ophthalmol. 11, 322, 1972.

72. Straschill, M. and Schick, F. Neuronal activity during eye movements in a visual association area of cat cerebral cortex. Expl Brain Res. 19, 467-477, 1974.

73. Lynch, J. C., Mountcastle, V. B., Talbot, W. H. and Yin, T. C. T. Parietal lobe mechanism for detecting visual attention. $J$. Neurophysiol. 40, 362-389, 1977.

74. WURTz, R. H. and Mohler, C. W. Enhancement of visual responses in monkey striate cortex and frontal eye fields. J. Neurophysiol. 39, 766-772, 1976.

75. BaIZER, J. S. and Robinson, D. L. Activity of prestriate neurons in behaving monkey. Soc. Neurosci. Abstr. 126, 1974.

76. GutTron, D. and MANDL, G. Eye movements and frontal eye-fields: electrical stimulation and unit recording in the awake cat. Neurosci. Abstr. 1, 356, 1975.

77. Bizzı, E. Discharge of frontal eye field neurons during saccadic and following cye movements in unanesthetized monkeys. Expl Brain Res. 6, 69-80, 1968.

78. Teuber, H. L. Perception. C. LXV. In Handbook of Physiology Neurophysiology, J. Field. (Editor), Vol. 3, pp. 1595-1668. Williams \& Wilkins, Baltimore, 1960.

79. Schlag, J., Petre Quadens, O., De Nee, C. and Goffe, B. Eye movements and occipital electrocortical rhythms: effects of stimulation of the frontal eyefield in the cat. J. Physiol., Paris 68, 343-350, 1974.

80. Hollander, H. and Sanides, D. The retinal projection to the ventral part of the lateral geniculate nucleus. An experimental study with silver impregnation methods and plasmic protein tracing. Expl Brain Res. 26, 329-342, 1976.

81. Montero, V. M., Brugge, J. F. and Beitel, R. E. Relation of the visual field to the lateral geniculate body of the albino rat. J. Neurophysiol. 31, 221-236, 1968. 
82. Mathers, L. H. and MascetTi, G. G. Electrophysiological and morphological properties of neurons in the ventral lateral geniculate nucleus of the rabbit. Expl Neurol. 46, 506-520, 1975.

83. Spear, P. D., Smith, D. C. and Wili.iams, L. I.. Visual receptive field properties of single neurons in cal's ventral lateral geniculate nucleus. J. Neurophysiol. 40, 390-409, 1977.

84. Hugries, C. P. and ATER, S. B. Receptive field properties in the ventral lateral geniculate nucleus of the cat. Brain Res. 132, 163-166, 1977.

85. Putkonen, P. T.S., Magnin, M. and Jeaninerod, M. Directional responses to head rotation in neurons from the ventral nucleus of the lateral geniculate body. Brain Res. 61, 407-411, 1973.

86. Magnin, M. and PUtKonen, P. T. S. A new reticular thalamic area: electrophysiological study of the thalamic reticular nucleus and of the ventral lateral geniculate complex of the cat. Expl Brain Res. 1978. In press.

87. MAGNin, M. and Fuchs, A. F. Discharge properties of neurons in the monkey thalamus tested with angular acceleration, eye movement and visual stimuli. Expl Brain Res. 28, 283-299, 1977.

88. Roucoux, A. and CrommbLinck, M. Eye movements evoked by superior colliculus stimulation in the alert cat. Brain Res. 106, 349-363, 1976.

89. Robisson, D. A. Eye movements evoked by collicular stimulation in the alert monkey. Vision Res. $12,1795-1808,1972$.

90. Strascinll, M. and Hormann, K. P. Activity of movement sensitive neurons of the cat"s tectum opticum during spontaneous eye movements. Expl Brain Res. 11, 318-326, 1970.

91. Arduin, A., Corazza, R. and Marzollo, P. Relationships of the neuronal activity of the supcrior colliculus to eye movements in the cat. Brain Res. 73, 473-481, 1974.

92. Roucoux, A. and Crommelink, M. Influence of nystagmic and spontaneous oculomotor activity on superior colliculus neurons in curarized cats. Experientia 27, 1181-1182, 1971.

93. BON, L., CORAYIA, R. and INCHINGolo, P. Neuronal activity correlated with eye movement in the cat pretectum. Neurosci. Lett. 5, 69-73, 1977.

94. Hayasir, Y., Nagata, T. and Iwama, K. Modulation of synaptic transmission in cat's superior colliculus by saccadic eye movements. Brain Res. 72, 162-167, 1974.

95. Nagata, T. and Hayashi, $Y$. The effects of eye movements upon excitability of cat superior colliculus as tested by electrical stimulation of the cortico-collicular pathway. Tohoku, J. exp. Med. 121, 47-56, 1977.

96. Wertz, R. H. and Mohler, Organization of monkey superior colliculus: enhanced visual response of superficial layer cells. J. Neurophysiol. 39, 745-765, 1976.

97. Goldperg, M. E. and WURTZ, R. H. Activity of superior colliculus in behaving monkey-II. Effect of attention on neuronal responses. $J$. Neumphysiol. 35, 560-574, 1972.

98. Robinson, D. L. and WURT7, R. H. Use of an extraretinal signal by monkey supcrior colliculus neurons to distinguish real from self-induced stimulus movement. $J$. Neurophysiol. 39, 852-870, 1976.

99. SCHILler, P. II. and KofRNeR, I: Discharge characteristics of single units in superior colliculus of the alert rhesus monkey. $J$. Neurophysiol. 34, 920-936, 1971.

100. Wurtz, R. H. and Goldrera, M. F. Superior colliculus cell responses related to eye movements in awake monkeys. Science $171,82-84,1971$.

101. SCHIller, P. H. and Stryker, M. Single-unit recording and stimulation in superior colliculus of the alert rhesus monkey. J. Neurophysiol. 35, 915-924, 1972.

102. Mohler, C. W. and Wurtz, R. H. Organization of monkey superior colliculus. Intermediate layer cells discharging before eye movements. J. Neurophysiol. 39, 722-744, 1976.

103. Erdmann, B. and Dodge, R. Psychologische Untersuchungen über das Lesen. Niemeyer, Halle, 1898. Quoted in MATIN [113].

104. Latour, P. L. Visual threshold during eye movements. Vision Res. 2, 261-262, 1962

105. Vol.KMANN, F. C., SCHICK, A. M. L. and RigGS, L. A. Time course of visual inhibition during voluntary saccades. J. opt. Soc. Amer. 58, 562-569, 1968.

106. Zuber, B. L. and STARk, L. Saccadic suppression: elevation of visual threshold associated with saccadic eye movements. Expl Neurol. 16, 65 79, 1966.

107. Stark, L., Kong, R., Schwartz, S. Hendry, D. and Bridgeman, B. Saccadic suppression of image displacement. Vision Res. 16, 1185-1187, 1976.

108. Durfy, F. H. and I omkroso, L. T. Llectrophysiological evidence for visual suppression prior to the onset of a voluntary saccadic eye movement. Natufe, Lond. 218, 1074-1075, 1968.

109. Gross, E. G., VAuGilan, H. G. and VAlcivstisi, E. Inhibition of visual evoked responses to patterned stimuli during voluntary eye movements. Electroenceph. clin. Neurophysiol. 22, 204-209. 1967.

110. Chase, R. and Kal.i., R. L. Suppression of visual evoked responses to flashes and pattern shifts during voluntary saccades. Vision Re's. 12, 215 220, 1972.

111. Brindeley, G. S. and LewiN, W. S. The sensations produced by electrical stimulation of the visual cortex. J. Physiol., Lond. 196, 479 493, 1968. 
112. Riggs, L., Merton, P. and Morton, M. Suppression of visual phosphenes during voluntary saccadic eye movements. Vision Res. 14, 997-1011, 1974.

113. MatiN, E. Saccadic suppression. A review and an analysis. Psychol. Bull. 81, 899-917, 1974.

114. Holt, E. Eye movement and central anaesthesia. Psychol. Monogr. 4, 3-45, 1903.

115. MiCHAEL, J. A. and StARK, L. Interactions between eye movements and the visually evoked response in the cat. Electroenceph. clin. Neurophysiol. 21, 478-488, 1966.

116. MACKAY, D. M. Elevation of visual threshold by displacement of retinal image. Nature, Lond. 225, 90-92, 1970.

117. Mitrani, L., MateffF, St. and YakimofF, N. Is saccadic suppression really saccadic? Vision Res. 11, $1157-1162,1971$.

118. KulikowSKi, J. J. and Leighton, D. A. Lack of centrifugal component in saccadic suppression. $J$. Physiol., Lond. 265, 28-29, 1976.

119. BROOKS, B. A. and FUCHs, A. F. Influence of stimulus parameters on visual sensitivity during saccadic eye movements. Vision Res. 15, 1389-1398, 1975.

120. COHEN, B. and Feldmar, M. Relationship of electrical activity in pontine reticular formation and lateral geniculate body to rapid eye movements. J. Neurophysiol. 31, 806-817, 1968.

121. Malcolm, L. J., Bruce, I. S. C. and Burke, W. Excitability of the lateral geniculate nucleus in the alert, non-alert and sleeping cat. Expl Brain Res. 10, 283-297, 1970.

122. Jeannerod, M. and Chouvet, G. Saccadic displacements of the retinal image: effects on the visual system in the cat. Vision Res. 13, 161-169, 1973.

123. KRÜGER, J. and FISHER. Strong periphery effect in cat retinal ganglion cells. Excitatory responses in ON- and OFF-center neurones to single grid displacements. Expl Brain Res. 18, 316-318, 1973.

124. BRIDGemaN, B. Reply to Brooks and Fuchs: exogenous and endogenous contributions to saccadic suppression. Vision Res. 17, 323-324, 1977.

125. MACH, E. Beitrage zur Analyse der Empfindungen. 1886.

126. KorNMUller, A. E. Eine Experimentelle Anästhesie der aüsseren Angenmuskeln am Menschen und ihre Answirkungen. J. F. Psychol. Neurol. 41, 351-366, 1931.

127. Brindley, G. and Merton, P. A. The absence of position sense in the human eye. J. Physiol., Lond. $153,127-130,1960$.

128. SieBECK, R. Wahrnehmungsstorung und storungswahrnehmung bei Augenmuskellahmungen. Albrecht. V. Graefes Arch. Ophthal. 155, 26-34, 1954.

129. Brindley, G. S., Goodwin, G. M., Kulikowski, J. J. and Leighton, D. Stability of vision with a a paralyzed eye. J. Physiol., Lond. 258, 65-66, 1976.

130. Stevens, J. K., Emerson, R. C., Gerstein, G. L., Kallos, T., Neufeld, G. R., Nichols, C. W. and Rosenquist, A. C. Paralysis of the awake human: visual perceptions. Vision Res. 16, 93-98, 1976.

131. Sherrington, C. S. Observations on the sensual role of the proprioceptive nerve supply of the extrinsic ocular muscles. Brain 41, 332-343, 1918.

132. Matin, L. A, possible hybrid mechanism for modification of visual direction associated with eye movements. The paralysed eye experiment reconsidered. Perception 5, 233-239, 1976.

133. MACKAY, D. M. and MitTeLSTAEDT, H. Visual stability and motor control (reafference revisited). In Cybernetics and Bionics, W. D. KeIDEL (Editor). Oldenbourg, Munich, 1974. 
RESUME

les laits experimertadx concernart le rôle possible dune decharge corollare dans la regalation des interacions visuelles et oculomotrices, son: passes on rever. live:s modos d'ation pour un tel mécanismo sont eruisagos. Tamlis que la simpe

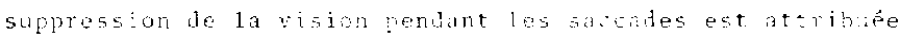
à un mécanisme pêripherifide, on propose que la dechargo

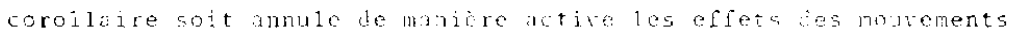
des yeux sur la visior, coit pernette levabuen l'origine et la cause de ces effets. I.e mćcanispe l'annulation pourrait être effectif au n:rcau sous-cortical et celui d'çáuation au riveau cortical.

\section{Deutschsprachife Lusammenfassung:}

Daten, die mögliche liole eines folgeentladurgsnechanismus bei der Regulation von visuell-oculomotonischen Intoraktionen betreffend, werden zusamenfessend betrachtet. Verschie dene Aktionsmbglichleiten fur einen solchen Mechanismus zur Verarbeitung visuelien informatior. rerden ciskutient. 310Be Unterdrickung von risuollen input wisrerd Blicksakeden wird zumeist als ein peripherer hecrar isms betrechtet. Is wird voneschaner, das polabontladwe ontrocer ein aktives

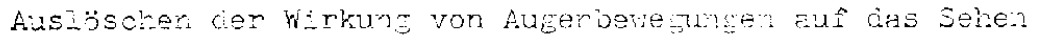
produzierer lonnte, ocion da.3 sio zur Auswortuns beiträgt, die eine Sakkade in eirer gegeberen visuellen Veranderuns provozient (Aus)Ibschurs lonite aut subcorticalen Eienen der visiellen Datenverarbeitune statsinden, die Ausvertung hingesen auf der corticalen ebene. 